\title{
The presentation of Bushmen in cultural tourism: tourists' images of Bushmen and the tourism provider's presentation of (Hai//om) Bushmen at Treesleeper Camp, Namibia
}

\author{
Anna Hüncke and Stasja Koot
}

\begin{abstract}
This article examines images of Bushmen in Namibian cultural tourism from two angles: that of the tourists and that of the community-based tourism provider. By looking at the tourist activities offered at Treesleeper Camp, it will be shown that in host-guest encounters, tourists' images of $(\mathrm{Hai} / / \mathrm{om})$ Bushmen interrelate with the images presented by the local hosts, and that tourists' perceptions and the images sought to be transmitted by the community-based local tourism provider are (partly) different. Tourists' quest for authentic Bushmen cultures often reflects the expectation of a pristine and exotic 'other' - an image that is derived from colonial views, anthropology, media and the tourism industry. But there are also tourists who are looking for Bushmen in a process of development. The community-based cultural tourism project of Treesleeper attempts to create awareness of Bushmen using their traditions to deal with current life challenges. The dual nature of the project is the starting point for showcasing the recreation of images as well as the tourism provider's ambivalence - in order to fulfil tourists' expectations - between the objectives to create awareness of the Hai//om Bushmen's cultural heritage and their contemporary life.
\end{abstract}

Keywords: community-based tourism, cultural tourism, Hai//om Bushmen, image creation, Namibia

In 2009/2010 Anna Hüncke conducted a six-month research at Treesleeper Camp in Tsintsabis, Namibia, for her Master's at the African Studies Centre, Leiden, The Netherlands. In 2011 she started a PhD on the fight against human trafficking in South Africa at the University of Constance, Germany. anna.huencke@gmail.com. Stasja Koot has Master's degrees in cultural anthropology and environmental studies. From 2003 until 2007 he lived and worked in Namibia, where he helped build Treesleeper Camp. In 2009 he started a PhD at Tilburg University, together with the African Studies Centre Leiden, The Netherlands, on the relation between Bushmen, tourism and protected areas. stasjakoot@gmail.com 


\section{Introduction and theoretical approach}

NGOs and rural people in African countries often associate economic profit and job opportunities with community-based tourism, which is specifically intended for poor communities and is characterised by empowerment, self-reliance and its small scale. It is a form of tourism that should be initiated, planned, owned, managed and controlled by local community members, based on their needs and wishes (Giampiccoli \& Nauright 2010: 52-53). In Africa and elsewhere, the role of culture is important in community-based tourism:

Africa is for many tourists $[\ldots]$ a culturally pristine and authentic continent, where different cultures can be met in a direct way. Though not so much the continent of 'High Culture' with impressive buildings and ruins and well-known historical events, Africa is the continent of local communities with authentic cultures. A few destinations $[\ldots]$ are specifically ethnic oriented, i.e. to those ethnic cultures rendered famous for whatever reason, anthropology included. (Van Beek 2007: 163)

It is in this regard that Bushmen in Namibia are attractive. Tourists expect presentations of their life and culture to be authentic, but what they perceive as authentic is their own construct, based on a historically given image and on the image industry generally. Authenticity is rather related to the expectations of an observer; the tourists' label of 'authenticity' is concerned with the pre-image of the 'other' with regard to themselves. Within tourism the dominant image is still that of 'unspoiled, pristine, genuine, untouched and traditional' Bushmen cultures and people (Handler 1986: 2) living close to nature - an image based on the views of European settlers, anthropologists, filmmakers, media and the tourism industry. However, it would be too easy to assume that all tourists seek the image of traditional Bushmen, as those tourists who look for contact with people of a different culture on an equal level are not accounted for by such a gaze. This demand can potentially be answered by community-based tourism endeavours, where the line between hosts and guests is often a lot thinner when compared to the private sector. Communitybased cultural tourism providers not only cater for their customers so as to benefit the local people involved economically, but also want to create respect for local culture by articulating an image of people using their traditions to deal with current life challenges (Hatton 1999: 3).

As a starting point the current touristic identity of Bushmen can be seen as having a 'dual nature', in which they are both the pristine cultural objects and the modernising producers of tourism (Garland \& Gordon 1999: 275). This idea is similar to what Steven Robins (2001) terms a 'double vision' in relation to non-governmental organisations (NGOs). The first label/vision posits the Bushmen as 'other', as they are often marketed (and market themselves), locating them outside time and space. The second, modernist label positions them as active agents and participants of the 
tourism industry, in which they choose to benefit from commodifying themselves. Interestingly, both discourses co-exist comfortably; at times only their status as the 'other' makes their modern role possible. In the end, it is their authentic 'other' that they have to sell (Garland \& Gordon 1999: 275-279). NGOs' and donor agendas are at the heart of this dual mandate, since on the one hand they try to promote the cultural survival of Bushmen - for example, by focusing on language projects while on the other hand they want to help them to become modern citizens - for example, by implementing democratic decision-making processes.

Western donors tend to show a desire for the authentic Bushmen, considered as a homogenous group, while simultaneously promoting democratic and neoliberal values (Robins 2001: 845-851). In following dual strategies, representatives of Western development thinking (including the state, donors and NGOs) have a tendency to create a division between modernity and tradition (Robins 2001: 841844, 2003; Sahlins 1999). However, according to Sahlins (1999), the survival of indigenous peoples ultimately depends on the integration of modern technologies - that is, on modern means of production, communication and transport - into indigenous cultures. Sahlins (ibid.) defines indigenous peoples' responses to these technologies as 'indigenous modernities', a term that was taken over by Robins (2003) in relation to Bushmen in South Africa. Robins (2003) notes that indigenous peoples tend to deploy hybrid responses to development aid initiatives, in accordance with their needs. He regards these responses - which adapt, accommodate, change or resist development programmes - as 'indigenous modernities'. We apply this notion in the context of Bushmen cultural and community-based tourism.

In this article on the cultural tourist activities of the community-based Treesleeper Camp project in Tsintsabis, Namibia, the authors examine how the hosts' presentations for tourists and tourists' reactions are interrelated with the intended effects of the project.' This will be viewed from the perspective of the 'dual nature' of Treesleeper, as described above, in which Bushmen are both traditional/authentic and modern at the same time.

\section{Cultural tourism}

Cultural tourism sometimes involves the appropriation of people as cultural objects, but it is also about the production of new forms of authenticity and, hence, about new kinds of subjects (Garland \& Gordon 1999: 271). The notion of authenticity has no fixed content, but cultural features such as an isolated existence lived in harmony with nature are part of the wider Bushmen image, and are therefore often construed as authentic. However, there are tourists who seek an authentic experience in which they are willing to accept that the tourism product itself does not necessarily have to be authentic. Against this backdrop, Garland and Gordon (ibid: 280-283) warn that 
tourists might easily regard Bushmen who are engaged in tourism as primitive and modern at the same time, midway in an imagined development process.

Tourists ascribe meaning to the various tourist attractions they encounter. This unifies the subject-object relation between tourists and sights, in which the sights symbolise the tourists' concept, rather than the ideas of the local people. In that way, ascribing meaning to a tourist attraction reduces local people and cultures to objects of the tourist gaze (MacCannell 1976: 109-133; Urry 2002: 13). This perspective does not necessarily consider the challenges facing a community-based tourism provider, and is in stark contrast to these authors' approach to encounters between hosts and tourists. Here, local people are seen as active stakeholders (Smith 2001) within the tourist bubble (Jaakson 2004; Judd \& Fainstein 1999; Van Beek 2003, 2007), which is defined as 'the whole of the arrangements in which the tourists are encased, allowing them to view the outside whilst being protected from misfortune' (Chabal, Engel \& De Haan 2007: 6). The bubble is designed by the tourism industry and local actors to ensure that the encounter between tourists and their hosts, in the African context, does not trigger tourists' fear of the unknown (Van Beek 2003: 254). The tourist bubble is less permeable if the distance between hosts and guests is maintained through arrangements that offer staged authenticity or front regions to tourists. This is constructed by the hosts and based on tourists' perceptions of what is authentic. However, the tourist bubble can be more permeable if tourists create experiences that allow them to transcend the frontstage (MacCannell 1976, term derived from Goffman 1959) and access the backstage where their hosts' lives actually unfold.

\section{Perceptions of Bushmen}

The 'Bushman Myth' (Gordon 1997: 118-141; Tomaselli 1995; 1999: 134) was and is a product of colonialism. During the German and South African colonial period in Namibia, Bushmen were perceived as inferior people, living in harmony with nature and closer to animals than to humans - an image created by missionaries and settlers (Gordon 1992; Wels 2004: 87). In 1907, the German administration established the Etosha Game Reserve within the roaming area of the Hai//om² Bushmen - an area which had already been reduced to make way for white farmland. The regime accepted the Hai//om within the park 'because they were considered to constitute part and parcel of the Etosha environment' (Suzman 2004: 225). Colonists often depicted African people in the context of their landscape (Wels 2004: 79), and in particular the Bushmen were associated with nature.

During the colonial era the Bushmen were objects of research, mainly in terms of their physical and behavioural distinctions. They were not only regarded as the most inferior race, unable to develop a full culture (Dieckmann 2007: 61; Gordon 1992: 
43-46), but also as wild people from the past, unable to survive in modern times. In accordance with this thinking, the Bushmen would either die out or would have to be 'tamed' (Gordon 1992: 137). In contrast, the German linguist, Wilhelm Bleek, had earlier argued that the Bushmen did not rank lowest amongst all of mankind (see Gordon 1992: 45-46; Skotnes 2007: 189).

The ambiguous image of nature-related and backward people can also be traced in the park policies of the South African apartheid government. After Germany had lost the First World War, the League of Nations (the predecessor of the United Nations) gave South Africa the mandate to prepare South West Africa (Namibia) for independence. In reality, however, South Africa acted as colonial power until Namibia was declared independent in 1990. Whereas initially the Hai//om were tolerated in Etosha - not least because 'for many park visitors encounters with Bushmen were the highlight of their trip' (Gordon 1998: 112) - they were later removed from the area. This was because of official perceptions of the growing importance of Etosha and its wildlife as a tourist attraction, and of Bushmen hunting large numbers of game (Friederich \& Lempp 2009: 72; Garland \& Gordon 1999: 274). Eventually, in 1954, the Hai//om were expelled from Etosha, and were left with little option but to work on the new settler farms where the demand for labour was high.

The visual accounts of expeditions at the time, which were made available for European and North American mass consumption, may very well explain the growing interest in the Bushmen. For example, in 1925 the Denver African Expedition, ${ }^{3}$ consisting of more or less self-proclaimed Africa experts, recorded visual material of the Bushmen. For mass distribution they created romanticised 'bushman-as-noblehunter images' (Gordon 1997: 123) - a depiction of fundamentally different people, which contrasted with their perception of advanced Western cultures. Consequently, the Bushmen were turned into the 'other' and became what Urry (2002) calls the 'object of [the] gaze'. In addition, a variety of books and films focused on the traditional Bushman image. Examples are The Lost World of the Kalahari (1958) and The Heart of the Hunter (1961), novels by Laurens van der Post, who also contributed to the visualisation of Bushmen as pristine primitives, living detached from the so-called modern world, with the television series The Lost World of the Kalahari (1956). The timeless depiction of the Bushmen in the movie The Gods Must Be Crazy (Uys 1980) or the documentary Hunters of the Kalahari (Derrick 1995), hosted by the Discovery Channel, continued to trade on myths and stereoptypes.

The Marshalls were among the first to conduct long-term research on specific Bushmen groups (Marshall, J. 1957; Marshall, L. 1976; Marshall, E. 1959). John Marshall's films were 'traditional' at first (The Hunters [1957]), but he later documented the lives of the Ju/'hoansi Bushmen of Nyae Nyae and the changes they had been going through since the 1950s. The best example of the latter was the series A Kalahari Family (2000), in which this process (including the influence 
of apartheid ideology and various development strategies) is shown together with Marshall's own changing perspectives throughout the years (Durington 2004; Van Vuuren 2009).

'Traditionalist' anthropologists such as DeVore and Lee (1968) regarded the Bushmen as having lived unchanged and in isolation until fairly recently, thus they were seen as a model of early mankind (e.g. Lee 1979). The 'revisionists', such as Denbow and Wilmsen (1986), criticised this perspective. They held that Bushmen groups had been in constant exchange with Bantu people, and that historical processes had led to the Bushmen's marginalisation, making them 'increasingly dependent on welfare and tourist handouts' (Wilmsen 1990: 140). This is reflected in images used by development organisations, which often depict the Bushmen as marginalised people in need of upliftment.

Still, the continuity of a romanticised Bushman image among academia, and its influence on a wide audience, were crucial for maintaining the tourism industry's image of pristine Bushmen. Tomaselli (2005: 112) states that 'men - e.g. the Bushmen - are ontologically rejoined with nature, which has now become a "scientific" pursuit in the interests of cultural tourism'.

Local white farmers often described the Bushmen as reliable workers, when compared to members of other ethnic groups, but they also perceived them as inferior to themselves. For example, a local German Namibian farmer in the research area described the Bushmen as living in the Stone Age and not thinking about the future. At the same time, the Bushmen farm workers regarded their employers, often referred to as 'Baas' (the boss), as exercising power over them through a social system termed 'baasskap' (Hüncke 2010: 83-85; Suzman 2000: 55-59; Sylvain 2001 ). The Bushmen's image is also often inferior among Bantu people, such as the Owambo and Herero. Many seem to believe that the Bushmen are not eager to work, and are unable to work without instruction (Hüncke 2010: 27, 29).

On the whole, missionaries, colonial officials, white farmers, Bantu people and anthropologists created images of the Bushmen and - intentionally or not -'othered' them. Among anthropologists, some saw the Bushmen as marginalised victims of the apartheid regime and the current influences of global capitalism (Hitchcock, Ikeya, Biesele \& Lee 2006: 1); others perceived them as real, pristine foraging people, living authentically as humanity's ancestors. In tourism, the latter image dominates and includes conceptions of the landscape the Bushmen live in (Buntman 2002: 6970; Taylor 2003: 259). This image is rooted in the historic context, but is incomplete from a contemporary perspective.

Outside stakeholders often overlook the views of the people they create images about. However, since the authors of this article regard local people as active stakeholders in the host-guest encounter, they consider not only the perceptions of Bushmen, but also their own views. 


\section{Treesleeper Camp, Tsintsabis, Namibia}

\section{Introduction to Treesleeper Camp}

Treesleeper Camp is located at the Tsintsabis resettlement farm, $110 \mathrm{~km}$ east of the Etosha National Park. Tsintsabis has more than 245 households (Ministry of Lands and Resettlement 2005) - about 1000 inhabitants (Berndalen 2010: 38). It has completely changed in character from a police station during the days of German occupation, to an army base during the South African protectorate (with the Hai//om often working for the South African Defence Force, to its current role as a resettlement area for primarily Hai//om and !Xun Bushmen. However, members of other ethnic groups, such as the Owambo, Damara, Kavango and Herero, have moved in because the Namibian government has pursued a policy of providing land for those who were displaced from their former settlement areas by the apartheid regime.

Etosha's proximity makes Treesleeper interesting for tour operators and tourists, who want to 'add some culture' to all their encounters with wildlife. It is far easier to get to Tsintsabis by following a tourist itinerary than it is to get to other places where you can experience Bushmen tourism, such as the Nyae Nyae Conservancy.

The objective of providing jobs for local people, particularly Bushmen, ${ }^{4}$ through tourism had been discussed in Tsintsabis since 1993, together with the plan to attract 'low and middle budget tourists by creating a community-based camp-site that can stimulate the small-scale economy of Tsintsabis' (Koot 2000: 62). Among the project initiators, i.e. the development committee consisting of villagers and Stasja Koot, the idea developed that the Hai//om could benefit from Etosha by attracting tourists for a stop-over after or before visiting the park. Another motivation was that Bushmen would be active contributors to cultural tourism. After Koot had engaged in planning, fundraising and lobbying, and after the Ministry of Lands and Resettlement (MLR) had allocated 10 ha of land, local people - especially young men - began constructing the campsite in 2004.

The camp is situated about $1.5 \mathrm{~km}$ from the village. The physical separation is meant to guarantee that neither local people nor tourists are bothered by each other. Also, the idea was for the camp to be situated in a naturally attractive environment. The name Treesleeper, a literal translation of 'Hai//om', was chosen to allude to the fact that foraging Hai//om used to sleep in trees when they were unable to return home. Guests to the campsite can become 'treesleepers' when they overnight on one of the tree-decks (platforms supported by tall poles).

The older generation, particularly, needed time to accept and understand the idea of Treesleeper (Troost 2007: 66). Building took a long time due to heavy rains, delays in delivery, and unforeseen costs. Treesleeper's activities were developed through local expertise and in August 2005, the first group of tourists arrived. To qualify for work, young people were offered training in tour guiding, bicycle repair, 
and computer courses. Treesleeper was complemented with a cultural centre in 2006 and a bar area in 2008. The camp has its own car for transporting supplies, while energy is produced by solar panels. To meet visitors' demands, Internet access is available at the campsite.

Before the construction began, two legal bodies were founded: in 2004/5, the Dutchman, Koot, together with his colleague, Bounin, created the Foundation for Sustainable Tourism in Namibia (FSTN) and Tsintsabis Trust. The latter consisted of Bushmen villagers and initially also of Koot, Bounin, and representatives from the local school, the Legal Assistance Centre (LAC), and the MLR. It was set up with the support of the LAC to establish a legal decision-making body. In this way the (mainly Bushman) community received group rights, while Namibian laws had then changed to reflect an anti-tribal standpoint (after apartheid) and were biased against group rights based on ethnicity (see also Widlok 1999; 2001). As Bounin and Koot were closely involved with the FSTN and the trust, they influenced many of the decisions made when developing Treesleeper, despite the intended bottom-up approach. The Working Group of Indigenous Minorities of Southern Africa (WIMSA) became suspicious that 'non-San people are Trustees' (Dieckmann 2007: 318) and during the initial years, an ambiguous relationship developed between WIMSA on the one hand, and the FSTN, the trust, and the community of Tsintsabis on the other.

After June 2007, when the FSTN withdrew, Voluntary Services Overseas (VSO) assisted the project for the next two years, and the position of a project manager was handed over to the local camp manager, //Khumûb. Today he is still in charge and Treesleeper can accommodate eight permanent employees. In addition, it helps to generate a small income for craft producers as well as for local dancers and singers of the traditional performance. The performance and a second activity, the bushwalk, take place on Treesleeper's premises, whereas the village walk allows tourists to visit local families. ${ }^{5}$

\section{Tourist activities at Treesleeper Camp}

Treesleeper presents images of the Bushmen and of Africa, adapted to tourists' expectations. However, it also seeks to present a complex image of the Hai//oms' past and contemporary way of life. As a community-based tourism project, the walls of its tourist bubble are more permeable than those of luxury tourism providers (Van Beek 2007: 152, 157). The three tourist activities, the meeting point between tourists and hosts, the five local guides who lead the bushwalk, and the local families who dance during the traditional performance or are visited during the village walk, play an important role in Treesleeper's image creation.

Tourists who took part in the activities had different motivations. Some tried to access the backstage of the 'other', in an attempt to get closer to them, while others appeared less interested in penetrating the tourist bubble and finding out about their 
hosts' background. Those tourists' expectations of authentic Bushmen were probably triggered by travel guides and tourist brochures.

\section{The bushwalk}

The tour groups, which consist of up to 20 members, are taken along a winding path with about 15 stops - all on the Treesleeper premises. During the two-hour walk, the English-speaking Hai//om guide, dressed in Western clothes, describes the observable fauna and flora and their (former) use for food supply as well as medicinal and hunting purposes. According to most tourists, the bushwalk is a very informative activity, with the guide identifying with what he presents.

Guests appreciate the personal contact with the guide, who is ready to answer their questions about living conditions in the village, and about his personal life. This could contribute to the tourists' feeling on the same level with him. At one of the stops the guide demonstrates how to set a snare trap for guinea fowl. Imitating the bird being trapped, while comparing the foraging lifestyle with the Bushmen's current lifestyle, the guide is simultaneously performer and mediator. This is very different at the end of the bushwalk, where the guide dresses up in traditional garb to demonstrate how to make fire. After preparing the guests for a meeting with another person, the guide distances himself from the role he will play at the end of the bushwalk and tries to explain that the fire-making will be pure performance - something which is not practised in contemporary Bushman life. One guide pointed out:

The walk is the best activity. I'm proud to be the guide during the walk because it is about the old lifestyle and nearly everything about the traditions is included. It is about hunting, gathering and tracking. I think it is good that we wear traditional outfits at the end as a kind of surprise for tourists. They don't know that before. I introduce this usually as 'At the end you are going to meet my twin brother'. (Pers. comm., 2 October 2009)

The hosts' ability to switch between a modern and a traditional approach becomes obvious in the guide's 'balancing act'. He intends to avoid creating an image of Bushmen as still living close to nature, but the pure demonstration of fire-making within a 'traditional' setting, with the guide dressed in skins, might stay in tourists' minds and influence their perceptions of Bushmen in general.

Interestingly, the tourists had different reactions when they observed the firemaking. Some tried to communicate with the guide, by asking questions about his actions. By attempting to keep relations on the same level as during the bushwalk, the tourists obviously intended to stay connected with the guide, as if bridging the gap between themselves and the culture being presented to them. Other tourists fell silent, looked around and avoided 'gazing' at the performer in his loincloth. A couple participating in the Bushwalk commented: 
The guide was really up to date. [...] He knew about so many things. [...] But the firemaking in the end was odd. We found the loincloth and the performance quite strange and pretty bold. (Pers. comm., 15 September 2009)

These tourists' reactions could have something to do with their sought image of a 'modern' Bushman - an image that the guide had complied with until that stage, but which tourists no longer found during the fire-making. By contrast, a member of a guided group took pictures of the performer's efforts at fire-making and pointed out:

This is why we booked the bushwalk. Our tour guide told us that there will be some traditional fire-making in the end. (Pers. comm., 14 August 2009)

Another tourist stated:

These guys really know how to live out there in the wild. [...] Stone Age people also knew how to make fire. (Pers. comm., 20 August 2009)

The fire-making performance, with the guide wearing a loincloth, seemed to fulfil the tourists' expectations of exoticism and confirmed their image of 'the other'.

It appears that this performance represents a less permeable part of the tourist bubble than the rest of the bushwalk because, thanks to the setting of two replicas of Bushman huts and the guide keeping to his role as a fire-making performer, tourists do not easily find a way to access the backstage.

\section{Traditional performance}

During the evening, on Treesleeper's premises tourists sit on tree trunks facing approximately ten performers (members of two economically deprived families visited during the village walk). The performers, who have been trained by Treesleeper staff, stand in a semi-circle, wearing traditional skins. Two male performers sing and dance, constantly moving around the campfire between the audience and the other singers, while the majority (women) sing and clap, keeping the rhythm with wooden boards. According to Treesleeper's home page, the 'traditional performance by Bushmen is something magic' (Treesleeper 2010). At the same time it is Treesleeper's intention that participants 'learn about the ritual dances and ceremonies and its [sic] meanings' (ibid.) with the help of the Treesleeper guide, who acts as a mediator (Cohen 1985; Smith 2001: 199). The camp manager, //Khumûb, stressed that Treesleeper does not want 'to create an image as if Bushmen were still dressed in traditional outfits'. Later on, he would justify the use of loincloth during the activity because "the performers show how Hai//om people lived in the past (...), [and] some tourists are keen to see people dressed in traditional clothes' (pers. comm., 24 September 2009). The performers are expected to appear on time for the dance if tourists have a booking, although Treesleeper personnel have stated that they are not very time-conscious. Again, this shows the thin line on which the 
hosts are continuously acting between two realities: their personal lives and the life expected thanks to their role in tourism.

Despite the guide's attempt to emphasise the show-like character of the performance, some tourists thought that during dances in the village the Bushmen also wear skins. One tourist even demanded to see a 'real traditional dance' in the Bushmen's 'real surroundings'. These tourists preferred to have the performers wearing skins, because it made the dances authentic for them. Other tourists apparently feared that the Bushmen would become submissive and marginalised, as in their view the skin cloth did not express the performers' pride in their culture, but made them 'objects performing for [...] tourists', as one tourist remarked. Looking for an authentic experience, these visitors tried to transcend the front stage - the performance - and sought information about locals' opinions and daily life - the backstage (MacCannell 1976).

Although the singers and dancers were free to choose their clothing for the performance, many agreed to wear skins. This was not necessarily proof of their negative self-perception as a result of an outside-determination, or as an impact of a performative discourse (Butler 1993), where other actors have produced and kept up a romantic, yet backward image of the Bushmen. Instead, it could mean that they were active stakeholders who used their customs to generate an income, and were proud of them. One performer commented:

I have no problem with traditional clothes [...]. It is good. We can show tourists our tradition and I can earn money. (Pers. comm., 30 October 2009)

Before the dances begin, the guide shortly explains the three different song categories: a happiness dance, an ancestral dance, and an initiation dance. During the ancestral dance, the older dancer brushes over tourists' faces with a feather, to wash away the guests' sins. A young tourist later mentioned:

I did not want this touching of my face and I did not understand anything about the dancing.

Another commented on the dance:

You know, I was not that fascinated. There was just a half-naked old man monotonously dancing around! (Pers. comm., 14 August 2009)

He then started to imitate the dancer by moving his buttocks and shuffling his feet. Some tourists demanded a more active performance, with drums included; they expected Bushman dances to be lively, and wanted the performers to interact with the audience. Apparently they had recreated the image of colourful and vivid African cultures, as popularised through the media, and transferred this to the Bushmen, 
considering those images to be authentic. ${ }^{6}$ The tourists had therefore constructed their own ideas of what a Bushman is or should be.

The guests repeatedly criticised the performance because they did not see the differences between the songs, and missed explanations about the meanings of the songs. Obviously, they had a problem making sense of the dances, which was expressed either in a feeling of distance or in disappointment. The performance did not seem to match their expectations of the Bushmen (Enevoldsen 2003: 494) and made the tourists look for a new position between what they were presented with, and what they expected.

Even if Treesleeper is successful in having tourists lose their romanticised image through traditional dances, the performance can make an ambiguous contribution toward creating awareness of Bushman culture. Thus, the encounter demands great skill on the part of the guide to mediate between the audience and the performers, so that the tourists might complement their pre-images of the Bushmen and be open to new insights. Still, this mediation is no panacea for all encounters. //Khumûb highlighted Treesleeper's trade-off between some tourists' expectations and what the performers are willing to show. He asked rhetorically:

The question is: What do tourists want to see? Do they want to see how Bushmen (...) [are]? Should we change because of tourists or should tourists accept how we are? (Pers. comm., 24 September 2009)

Indeed, in the village one of the dances, the ancestral dance, was still being practised for healing purposes. Some performers were convinced that the performance at Treesleeper had helped them rediscover their rituals and customs, even though it primarily represented a source of income. In this respect, the performance for tourists has become a new survival strategy with the means of culture.

\section{The village walk}

According to Treesleeper's (2010) web page, the village walk allows participants 'to get a better understanding of a culture in which traditions have now met the "modern world". This activity focuses on the Bushmen's current way of life and does not 'exhibit Bushmen people in traditional clothes' (ibid.). Halfway through the tour the group visits two homesteads located about $2 \mathrm{~km}$ from the village centre, belonging to a !Xun and a Hai//om family. Both families, who are among the poorest in Tsintsabis, consist of approximately ten people who generate an income through occasional work and tourist visits.

The families live in self-constructed huts built predominantly from natural materials, though some plastic sheeting is used as well. The huts were constructed with advice from Treesleeper staff and reflect the character of former Hai//om and !Xun housing. In the second homestead, a well-known !Xun traditional healer 
presents bow and arrows and describes the practice of hunting, drawing through the line to modern-day living by pointing out that hunting is illegal in most places. Still, both families occasionally hunt with traps and gather edible plants. The encounter with the traditional healer exemplifies Treesleeper's objective to hint at rites and customs during the village tour, obviously meant for tourists interested in the foraging lifestyle. Arguably, the visit to the homesteads can be called a performance for tourists because most villagers live in housing with corrugated iron sheets or in brick buildings, and bow-hunting is hardly practised today. A Treesleeper guide underlined the show character by pointing out:

The village tour is just a show, [...] one of the !Xun houses is not exactly built in the style as these people used to build houses [...]. They also do not always speak!Xun, but I as a guide just say that they do. (Pers. comm., 25 September 2009)

However, during different encounters in the central village, tourists were shown local people sleeping outside and villagers preparing meals or brewing tombo (a local alcoholic drink). These are clearly backstage activities.

At the homesteads, young tourists in particular were often embarrassed about taking photographs, due to the perceived poor living conditions of the hosts and the tourists' wish to respect their privacy. Apparently they wanted to interact with the families on the same level, but did not want local people to become an 'object of their gaze', thereby distancing themselves from the type of tourist Urry (2002) describes. Some anthropologists, who prejudge tourism as impacting hosts negatively (e.g. Smith 1977), would also have regarded taking photographs as an inappropriate exhibition of their hosts even if - or exactly because - the hosts received compensation (usually in the form of food) at the suggestion of staff members. An elderly man pointed out:

Tourists (...) take photos of us. That is good because they bring us food (...) We (...) feel good if the tourists take photos of us, then we know that tourists like us. (Pers. comm., 1 November 2009)

Obviously, taking photographs fostered the hosts' self-esteem, and they did not feel like exhibited objects when they received some token of appreciation in return. From this point of view the tourists' small gifts were not a means of aid, but a compensation for services. And though the hosts often described themselves as poor and obviously wanted to capitalise on their poverty through the tourists' gifts (for a similar observation, see Tomaselli 1999), they did not seem to regard their lives as desperate as perceived by many tourists. Indeed, a few tourists even cried during the village walk because of the poverty they encountered, which made the local staff wonder whether they felt sick or were in pain.

In other situations, too, the hosts were astonished by their guests' behaviour. A former guide commented: 
Tourists are funny. They stop for small things. They look at small insects and take photos of them, but they don't want to try [to eat] termites when I tell them that we collected some yesterday. (Pers. comm., 15 November 2009)

Thus, the hosts also identified "the "ultimate, distant other" in terms of their own main values and their own interests' (Van Beek 2003: 286).

Despite their quest for new experiences (Urry 2002), some tourists perceived the poverty of their hosts as shocking, obviously because it was not part of their expected image and stood in contrast to their desire to feel comfortable (Van Beek 2007). This shows that the tourist bubble of the village walk is rather permeable, exposing tourists to some parts of the 'real-life situation' (Treesleeper 2010) in the backstage (MacCannell 1976).

With the village walk, Treesleeper is certainly successful in showing tourists more than only the image of pristine Bushmen, but tourists' perceptions of needy and helpless Bushmen correspond to the image of backward, undeveloped or marginalised people. This negative perception does not reflect Treesleeper's positive emphasis on Bushmen using their traditions to deal with everyday life challenges.

\section{Conclusion}

Hosts' and guests' encounters during Treesleeper's activities open up an exchange between people from different backgrounds. Though all tourists have an individual experience, the authors observed that tourists who were interested in communitybased tourism tended to have two different images: a romanticised image of their hosts as practising customs and rites and living closely connected to nature, or the perception of modern Africans in the process of development.

The image of pristine Bushmen is promoted by the tourism industry to attract customers; for Treesleeper this image involves a trade-off. The project seeks to satisfy its customers as an economic endeavour, but as a cultural and communitybased development project its aim is to engender respect for contemporary Bushmen. Tourists who seek a modern Bushman, making use of his cultural knowledge, try to position themselves and their hosts on the same level. They imagine hosts who are different from tourists in as far as they have retained their cultural knowledge, but who resemble tourists as modern people. This confirms Garland and Gordon's (1999) concept of tourists who are looking for an authentic experience by seeking the effect their own visit has on the daily lives of these people. In other words, they want to access the backstage. They suppose that Bushman culture is changing and are ready for new experiences, instead of looking for the authentic, pristine people.

However, Treesleeper's responses to development initiatives in tourism are of hybrid discrepancy, and traditional and modern aspects in the Bushmen's activities show how they partly use 'indigenous modernities' (Robins 2003). For example, the 
Treesleeper home page describes the traditional performance as a 'magic' experience. The dancing at night around a blazing fire, with a 'traditional' hut and people in loincloths, can contribute to the 'magic'. However, the performers are free to wear everyday clothing and have agreed to be trained by Treesleeper in order to earn a small income. Quite a few tourists regard them neither as traditional Bushmen, nor as skilful dancers and singers. The village tour is marketed as backstage and 'real life', but is described by a tour guide as a show, while the bushwalk, with its strong focus on traditional life, is mostly done in Western clothing and gives guests an opportunity to discuss the tour guide's personal life, or to learn about the contemporary situation of the villagers. These discrepancies allow tourists to interpret either the performances as authentic or their visit as an authentic experience (cf. Garland \& Gordon 1999), often depending on the image they had of Bushmen before their visit.

Treesleeper's visitors seek new experiences in uncovering the secrets of hunting and gathering during the bushwalk, in watching the dancers and listening to songs during the traditional performance, and in getting to know local people's way of life during the village walk, while feeling comfortable themselves. When the back regions are visited for an authentic experience during the village walk, the hosts' poverty can come as a shock to the tourists. But the shock may confirm that the tourist is having an authentic experience - one which can also be gained by interacting with the bushwalk tour guide, as he describes the dire economic situation of many villagers, or prevalent diseases in Tsintsabis.

The combination of community-based tourism and cultural tourism creates an ideological paradox, which is often found in development projects, because they focus on contrasting goals. The community-based concept emphasises the agency of local actors who deliberately participate in a common project or, in other words, on the 'modern citizens-in-the-making' (Robins 2001: 833). By contrast, the cultural approach emphasises that the cultural heritage of traditional groups, the 'First People' (ibid: 835), needs to be preserved. Garland and Gordon (1999: 283), citing Homi K. Bhabha, warn that while tourism might provide the hosts with "substantial benefits, it is also ensuring that they remain permanently "not quite like us, not yet". This might be one strong, long-term effect of tourism. Robins (2001: 835) criticises donor organisations for having 'double vision' in that they follow both approaches at the same time.

The authors of this article agree with Robins that this 'double vision' exists and in fact has been internalised at Treesleeper as a 'double nature'. This can be explained by the fact that it was set up as a community-based development project, which would be impossible without the pristine image of the Bushmen. Since development approaches for indigenous people anticipate that they will use their own cultures as a means to strive for so-called development, the pristine image of Bushmen is catered for. 
For tourism to be classified as developmental, both the modern and the traditional are essential. However, the necessity of the latter renders the image creation in the tourism industry dependent on pristine, authentic Bushmen. Therefore, 'real' backstage experiences are unlikely to evolve in Bushmen tourism, though Treesleeper is rather advanced in this respect. The project is characterised by the hosts' efforts to bring about a balance between the modern and the traditional world and their images, rather than being stuck halfway between the two. Using 'indigenous modernities' (Robins 2003; Sahlins 1999) and giving hybrid responses, they manoeuvre between the options at stake.

\section{Notes}

1 The article is based on Anna Hüncke's six-month research at Treesleeper Camp on the effects of community-based and cultural tourism in Tsintsabis, Namibia, in 2009/10. Part of the fieldwork encompassed 40 semi-structured formal and informal interviews with local inhabitants, of which 25 were translated from Hai//om to English by a research assistant. Furthermore, informal interviews were conducted with tourists and tour guides during activities or encounters at reception. Also, participant observation played a role during encounters with tourists and with the people of Tsintsabis. The article is backed up by Stasja Koot's various stays in Tsintsabis between 1999 and 2010, when he lived, worked and conducted research there. From 2002 to 2007 he helped the community of Tsintsabis build Treesleeper Camp, speaking English and Afrikaans with the inhabitants.

2 The symbols '//' in Hai//om and '!' in the name !Xun and '/" in Ju/'hoansi represent click sounds in Khoisan languages (cf. Barnard 1992).

3 Etosha was only one stop during the expedition, which had as its goal searching for the relation between mankind and animals in the Kalahari (Gordon 1997).

4 Except for one Damara woman, all staff members encountered during the research period were Hai//om or !Xun.

5 According to Treesleeper's guest questionnaires, most of the visiting tourists (approximately $80 \%$ ) participate in the bushwalk, 50 per cent part in the village walk and about 40 per cent book the traditional dancing.

6 However, close to Chetto in Bwabwata National Park, Namibia, Khwe Bushmen started the Hyemacan //Au group, which performs with drums, due to the influence of Bantu tribes moving into the area. In addition, some Ju/'hoansi Bushmen also use drums in their healing sessions, for example in /Xai /Xai, Botswana (Katz, Biesele \& St. Denis 1997).

\section{References}

Barnard, A. 1992. Hunters and herders of Southern Africa: a comparative ethnography of the Khoisan peoples. Cambridge: Cambridge University Press.

Berndalen, J. 2010. The road to hell. Insight Magazine 10: 38. 
Buntman, B. 2002. Travels to otherness: Whose identity do we want to see? Senri Ethnological Studies 60: 65-84.

Butler, J. 1993. Bodies that matter: on the discursive limits of sex. New York: Routledge.

Chabal, P., U. Engel and L. de Haan. 2007. Introduction. In African alternatives, ed. P. Chabal, U. Engel and L. de Haan, 1-9. Leiden: Brill.

Cohen, A.P. 1985. The symbolic construction of community. London: Tavistock.

Denbow, J. and E. Wilmsen. 1986. Advent and course of pastoralism in the Kalahari. Science 234: 1509-1515.

DeVore, I. and R. Lee. 1968. Man, the hunter. Chicago: Aldine Publication.

Dieckmann, U. 2007. Hail/om in the Etosha region: a history of colonial settlement, ethnicity and nature conservation. Basel: Basler Afrika Bibliographien.

Durington, M. 2004. John Marshall's Kalahari family. American Anthropologist 106(3): $589-594$.

Enevoldsen, K. 2003. See no evil, hear no evil. An 'outsider's' encounter with cultural tourism in South Africa. Cultural Studies: Critical Methodologies 3(4): 486-502.

Friederich, R. and H. Lempp. 2009. Verjagt ... Verweht ... Vergessen ... Die Hail/om und das Etoschagebiet. Windhoek: MacMillan Education Namibia.

Garland, E. and R. Gordon. 1999. The authentic (in)authentic: Bushman anthro-tourism. Visual Anthropology 12(2): 267-287.

Giampiccoli, A. and J. Nauright. 2010. Problems and prospects for community-based tourism in the new South Africa: the 2010 FIFA World Cup and beyond. African Historical Review 42(1): 42-62.

Goffman, E. 1959. The presentation of self in everyday life. Harmondsworth: Penguin.

Gordon, R. 1992. The Bushman myth: the making of a Namibian underclass. San Francisco: Westview Press.

Gordon, R. 1997. Picturing Bushmen: the Denver African expedition of 1925. Claremont: David Phillip Publishers.

Gordon, R. 1998. Backdrops and Bushmen: an expeditious comment. In The colonising camera: photographs in the making of Namibian history, ed. W. Hartmann, J. Silvester and P. Hayes, 11 1-117. Windhoek: Out of Africa.

Handler, R. 1986. Authenticity. Anthropology Today 2: 2-4.

Hatton, M. 1999. Community-based tourism in the Asia-Pacific. Toronto: School of Media Studies at Humber College. http://cullin.org/cbt (accessed 12 July 2010).

Hitchcock, R., K. Ikeya, M. Biesele and R. Lee. 2006. Introduction: updating the San, image and reality of an African people in the twenty-first century. Senri Ethnological Studies 70: $1-42$.

Hüncke, A. 2010. Treesleeper Camp: impact on community perceptions and on image creation of Bushmen. Unpublished Master's thesis, African Studies Centre, University of Leiden.

Jaakson, R. 2004. Beyond the tourist bubble? Cruise ship passengers in port. Annals of Tourism Research 31(1): 44-60.

Judd, D. and S. Fainstein. 1999. Constructing the tourist bubble. In The tourist city, ed. D. Judd and S. Fainstein, 35-53. New Haven: Yale University Press. 
Katz, R., M. Biesele and V. St. Denis. 1997. Healing makes our hearts happy: spirituality \& cultural transformation among the Kalahari Ju/'hoansi. Rochester, Vermont: Inner Traditions.

Koot, S. 2000. Resettlement in Tsintsabis: Namibian Bushmen in a changing world Unpublished Master's thesis, Department of Anthropology, University of Utrecht.

Lee, R. 1968. What hunters do for a living or how to make out on scarce resources. In Man the hunter, ed. R. Lee and I. DeVore, 30-48. New Jersey: Transaction Publishers.

Lee, R. 1979. The !Kung San: men, women and work in a foraging society. Cambridge: Cambridge University Press.

MacCannell, D. 1976. The tourist: a new theory of the leisure class. New York: Schocken.

Marshall, E. 1959. The harmless people. New York: Vintage Books.

Marshall, L. 1976. The !Kung of Nyae Nyae. London: Harvard University Press.

Ministry of Lands and Resettlement. 2005. Project proposal for ongoing resettlement development projects. Directorate of Resettlement. Windhoek: Ministry of Lands and Resettlement.

Robins, S. 2001. NGOs, 'Bushmen' and double vision: the $\neq$ khomani San land claim and the cultural politics of 'community' and 'development' in the Kalahari. Journal of Southern African Studies 27(4): 833-853.

Robins, S. 2003. Whose modernity? Indigenous modernities and land claims after apartheid. Development and Change 32(2): 265-285.

Sahlins, M. 1999. What is anthropological enlightenment? Some lessons of the twentieth century. Annual Review of Anthropology 28: i-xxiii.

Skotnes, P. 2007. Claim to the country: the archive of Lucy Lloyd and Wilhelm Bleek. Auckland Park: Jacana Media.

Smith, V. 1977. Hosts and guests: the anthropology of tourism. Philadelphia: University of Pennsylvania Press.

Smith, V. 2001. The culture brokers. In Hosts and guests revisited: tourism issues of the $2 \mathrm{I}^{\mathrm{st}}$ century, ed. V. Smith and M. Brent, 275-282. New York: Cognizant Communication.

Stewart, H. and A. Barnard. 2002. Introduction: self- and other-images of hunter-gatherers. Senri Ethnological Studies 60: 1-4.

Suzman, J. 2000. Things from the bush: a contemporary history of the Omaheke Bushmen. Basel: P. Schlettwein Publishing.

Suzman, J. 2004. Etosha dreams: an historical account of the Hai//om predicament. The Journal of Modern African Studies 42(2): 221-238.

Sylvain, R. 2001. Bushmen, boers and baasskap: patriarchy and paternalism on Afrikaner farms in the Omaheke Region, Namibia. Journal of Southern African Studies 27(4): $717-737$.

Taylor, M. 2003. 'Wilderness', 'development', and San ethnicity in contemporary Botswana. In San and the state: contesting land, development, identity and representation, ed. T. Hohmann, 255-279. Köln: Rüdiger Köppe Verlag.

Tomaselli, K. 1995. Introduction: media recuperations of the San. Critical Arts 9(2): i-xxii.

Tomaselli, K. 1999. Psychospiritual ecoscience, cultural tourism and dance: the Ju/'hoansi and cultural tourism. Visual Anthropology 12: 185-196. 
Tomaselli, K. 2005. Where global contradictions are sharpest: research stories from the Kalahari. Amsterdam: Rozenberg Publishers.

Treesleeper. 2010. Treesleeper Campsite. www.treesleeper.org (accessed 29 June 2012).

Troost, D. 2007. Community-based tourism in Tsintsabis: changing cultures in Namibia. Unpublished bachelor thesis, Faculty of Marketing, Tourism and Leisure, InHolland University of Applied Sciences, Haarlem.

Urry, J. 1990/2002. The tourist gaze: leisure and travel in contemporary societies. London: Sage Publications.

Van Beek, W. 2003. African tourist encounters: effects of tourism on two West African societies. Journal of the International African Institute 73(2): 251-289.

Van Beek, W. 2007. Approaching African tourism: paradigms and paradoxes. In African alternative, ed. P. Chabal, U. Engel and L. de Haan, 145-171. Leiden: Brill.

Van der Post, L. 1958. The lost world of the Kalahari. London: Penguin Books.

Van der Post, L. 1961: The heart of the hunter. London: Vintage.

Van Vuuren, L. 2009. 'And he said they were Ju/Wasi, the people....' History and myth in John Marshall's Bushmen films, 1957-2000. Journal of Southern African Studies 35(3): 557-574.

Wels, H. 2004. About romance and reality: popular European imagery in postcolonial tourism in southern Africa. In Tourism and postcolonialism: contested discourses, identities and representation, ed. C. Halland and H. Tucker, 76-91. New York: Routledge.

Widlok, T. 1999. Living on Mangetti: 'Bushman' autonomy and Namibian independence. Oxford: Oxford University Press.

Widlok, T. 2001. Equality, group rights, and corporate ownership of land. Max Planck Institute Working Paper No. 21. Unpublished manuscript, Halle.

Wilmsen, E. 1990. We are here: politics of aboriginal land tenure. Berkeley: University of California Press.

\section{Filmography}

Derrick, W. 1995. Hunters of the Kalahari. [Film.] Produced by Essential TV, Discovery Channel.

Marshall, J. 1957. The Hunters. [Film.] Documentary Educational Resources USA.

Marshall, J. 2000. A Kalahari Family. [Film.] Kalfam Productions, Inc.

Uys, J. 1980. The Gods Must Be Crazy. [Film.] Mimosa Films, Botswana.

Van der Post, L. 1956. The Lost World of the Kalahari. [Television series.] London: BBC. 